\title{
Is Technical Competency Necessary for Client Project Manager? An Empirical Study of Commitment-making Officers (PPK) in Indonesian Public Construction
}

\author{
Kartika P Negara $^{\mathrm{a}}$, Fiona Lamari ${ }^{\mathrm{b}}$, Connie Susilawati ${ }^{\mathrm{c}}$, Bambang Trigunarsyah $^{\mathrm{d}}$ \\ ${ }^{a}$ Civil Engineering Department, Engineering Faculty, Brawijaya University (UB), Indonesia \\ E-mail: kartika_puspa@ub.ac.id \\ ${ }^{b}$ School of Built Environment, Science and Engineering Faculty, Queensland University of Technology (QUT), Australia \\ E-mail: fiona.lamari@qut.edu.au \\ ${ }^{c}$ School of Economics and Finance, QUT Business School, Queensland University of Technology (QUT), Australia \\ E-mail: c.susilawati@qut.edu.au \\ ${ }^{d}$ School of Property, Construction and Project Management, RMIT University, Australia \\ E-mail: bambang.trigunarsyah@rmit.edu.au
}

\begin{abstract}
Public construction in Indonesia still suffering failure in the last few decades. Evidence shows that one of the source factors to public construction failures was a lack of technical-area understanding in Commitment-Making Officers (Pejabat Pembuat Komitmen, PPK). Moreover, since PPK has various academic disciplines, evidence shows that many PPK from local government agencies are reluctant to be assigned as a PPK because they are concerned about their lack of understanding of basic construction knowledge and its consequences. This paper aims to identify the importance level of PPK's technical competency in managing public construction projects. In this study, self-administered questionnaires were distributed to PPK from East Java, Southeast Sulawesi, and Gorontalo provinces, and interviews were conducted to confirm the results. The findings show that having technical competency is necessary for PPK regardless of their academic disciplines. However, they do not need to understand every single detail of the construction project, but they are expected to understand a big picture of construction methods that enable them to act as a knowledgeable contributor in the construction delivery. This study contributes to the existing knowledge of project manager competency by providing insight into project manager from the client-side in the public construction projects.
\end{abstract}

Keywords — client project manager; commitment-making officer; PPK; public construction.

\section{INTRODUCTION}

Public construction in Indonesia still cannot escape from project failure in the last decade [1]. Time delays, cost deviations, or improper project qualities were keep occurred in Indonesian public construction [1-3]. 12 out of 34 public buildings in Indonesia failed to comply with the quality, cost, or schedule requirements in the contracts [1]. Recent evidence reported that 53 public construction in Indonesia indicated failures, causing loss of local government budget around IDR 1.2 billion [4]. An investigation conducted by an Indonesian local government found that a lack of PPK technical competency was one of the primary sources behind these public construction failures [4].

Some of PPK have considered a lack of understanding of basic construction knowledge in some local government agencies. With some of their academic disciplines were not in the engineering area, they reluctant to be assigned as a PPK, an in-house project manager from the government side in public construction projects. Recent evidence revealed that no one civil servants in a health agency at a local government, whom the majority have academic health disciplines, was willing to be assigned as a PPK to manage public construction projects [5]. Even though technical teams assist PPK manages projects on high-level progress and are responsible for the decisions. $\mathrm{Ng}$, Rose, Mak, and Chen [6] noted that the lack of technical knowledge on client project managers could hinder their understanding and efficiency in making decisions related to the problem resolution process.

Do these conditions lead to the intriguing question of the importance level of technical competency for a commitment- 
making officer (PPK) in managing public construction project? Is there any influence of academic discipline toward PPK's current level and preferred level of technical competency? Even though extensive research has been carried out on project manager competency, few studies discuss in-house project manager competency from the government agencies in the public construction sector, specifically investigate technical competency.

This paper aims to (1) investigate the importance level of technical competency for PPK in managing public construction projects, and (2) assess the perceived and the preferred level of PPK's technical competency. To achieve the aims, first, brief literature on Client Project Manager and PPK is presented to understand those roles in the Indonesian public construction project. Literature regarding technical competency in projects is then provided, followed by research methodology, results, and discussion. Finally, the conclusions, recommendations, and limitations of this study are provided in the last section. This study is expected to generate insight into the importance level of technical competency for PPK to achieve public construction success. It is also expected to provide a useful reference for policymakers intending to stipulate policies to develop PPK competency

\section{MATERIAL AND METHOD}

\section{A. Literature Review}

The notion of competency emerged from the psychology field to critique college admission and job entrance procedures, which are merely based on an intelligence test [7]. Although the first studies of competence-based emerged to replace task-based in the educational and job sectors, competence has thrived in various sectors, including the construction sector.

A construction project manager needs to have the required competency because a competent project manager leads to project success. A project manager responsible for managing public projects also needs to have the necessary competency since public construction projects have their characteristics compared to private construction projects.

Confined by specific government regulations, employ public funding, and demanded to be accountable to the public are the boundaries of public construction that must be recognized by public project managers [8]. The awareness of public project managers on the distinct characteristic of public projects will lead them to manage public construction effectively and efficiently [8]. However, this awareness is insufficient to equip public project managers to achieve project goals during their engagement throughout project construction phases. They should have a set of competencies that assist them in performing their roles.

A project manager's role, either from the contractor side or client-side [9], is essentials in managing construction projects [10]. Whilst, a project manager from the contractor side responsible for all on-site activities, a project manager from the client-side responsible for project administration, coordination, and construction efforts [9]. Jawahar-Nesan and Price [11] describe the client's role which is preparing and organizing the project, developing project definition (including conducting a feasibility study), ensuring that project participants (contractors, professionals, etc.) are selected effectively, organizing a joint management team, monitoring safety management, tracking project performance, communicating with and motivating project participants, coordinating all project participants, and documenting project delivery. Hutchison [12] also explains that client responsibilities are plan the project's strategy, establish a positive project environment and monitor it, develop a clear business case, oversee high-level progress, be ready to take corrective actions, communicate with the client organization and project team, understand the needs of all parties, and learn from other clients and projects.

The role of client project managers is crucial to project success [13]. As a client facilitator and coordinators [14], they must engage in construction projects and ensure project goals are achieved. Even though client project managers are not the construction doer [14], their competency is required and contribute to project success [15].

In the Indonesian public construction project, a client project manager is well known as a Commitment-making officer / Pejabat Pembuat Komitmen (PPK). A PPK is an inhouse civil servant in the government institution or agency and is assigned by the government to manage the state/ local government budget expenditure includes expenditure for public construction services. Their responsibilities cover plan construction project, estimate owner's cost, plan term of reference of the project, draft contract, establish support team, sign contract (if it is delegated by top management), supervise contract implementation, document, and inform project to the top management, and accept the project.

PPK's duties in the construction project are quite complex. Thus, understandably, many PPK from non-engineering academic in local governments reluctant to be assigned as a PPK in managing public construction projects they concern about their lack of basic understanding on projects knowledge. Recent investigations from a local government revealed that one of the significant contributions of 53 construction projects' failure was a lack of PPK technical competency [4].

Technical competency is understanding the methods to undertake specific construction works and the required machinery and equipment to complete construction [16]. In agreement, El-Sabaa [17] defined technical competency as understanding and proficiency in method or process and procedure of a specific construction work that requires specialized knowledge from the specific discipline. He outlined technical skills into special knowledge on tool usage and techniques; project knowledge, methods, process, and procedures; technology required and the skill in using computers. In this paper, technical competency refers to construction methods.

Understanding technical knowledge is required to (a) understand the integration of technical features with project cost, quality, and schedule requirements, (b) manage technical problems, (c) coordinate and communicate with technical specialists, and (d) make decisions [18]. It helps the client representative/ client project manager contribute to the construction problem-solving process, not as an expert but as an interested and knowledgeable contributor to the construction project team [19]. 


\section{B. Research Methodology}

The scope of this paper is to investigate the importance of technical competency for PPK who manage public construction projects. This research employed a survey design, a type of research design dominated by a questionnaire and interview for gathering data and is essentially a snapshot in time [20].

Regarding research strategy, Creswell [21] argued that a qualitative research strategy is useful for identifying a variable, describing phenomena not yet addressed in theory literature, and exploring social phenomena in-depth. In contrast, a quantitative research strategy is useful for measuring the response of many people. However, each of those research strategies suffers from drawbacks [22], and as such, many researchers combine both qualitative and quantitative to acquire greater benefits from both research strategies. Thus, a mixed-method research strategy was used for this research by combining both qualitative and quantitative research strategies. This rationale approach is that neither a qualitative nor quantitative strategy is adequate to provide a comprehensive understanding regarding PPK technical competency. Therefore, qualitative, and quantitative strategies cannot be conducted independently. This rationale is congruent with Creswell, Klassen, Plano Clark, and Smith [23], who argued that a mixed method is suitable for answering research questions where either qualitative or quantitative methods would be insufficient and both strategies are therefore required to acquire a comprehensive understanding.

This study employed a questionnaire survey to assess the importance of technical competency and semi-structured interviews to confirm the result's questionnaire analysis. Eighty-eight questionnaires were collected from all the population PPK who employed in 34 local government agencies in three provinces: East Java, Southeast Sulawesi, and Gorontalo provinces. These locations were selected from three strata: the high, middle, and low average of construction expenditures during 2007-2015 in 34 provinces in Indonesia [24]. As a note, the respondents were limited to only PPK who have experience in managing public construction projects and excluded PPK who managed public goods. Respondents were asked to assess the importance level of technical competency using a Likertscale from 1 to 5,1 refers to not important, 2 refers to slightly important, 3 refers to important, 4 refers to important, and 5 is extremely important. The results were then analyzed using descriptive and inferential statistical analysis using SPSS v24.

The respondents' profile shows that $68.2 \%$ of respondents were from East Java provinces, $21.6 \%$ of respondents were from Southeast Sulawesi, and $10.2 \%$ of respondents were from Gorontalo provinces. The number of respondents in East Java provinces was the highest since the province is located on Java island in which the capital city of Indonesia is located, and many public constructions were constructed. Meanwhile, Gorontalo province was the farthest province from Java island and is categorized a new province compared to the others. The questionnaire profile also shows that $78.4 \%$ of respondents were PPK who manage construction projects and have an engineering academic discipline background. Meanwhile, $21.6 \%$ of respondents have non-engineering academic discipline background.

Meanwhile, semi-structured interviews were conducted with eleven PPK who experiences in managing public construction projects. $36.4 \%$ of interviewees have project experiences for less than five years, $45.4 \%$ of interviewees have experiences 5-10 years of experience, and $18.2 \%$ have experience for more than ten years.

\section{RESULTS AND DISCUSSION}

\section{A. Results}

This subsection presents the summaries of the questionnaire survey and interviews analysis in addressing the research objectives.

1) Importance level of technical competency: The finding shows that technical competency was perceived as the "important" competency required by PPK in managing public construction projects (mean score: 4.31, standard deviation: 0.6). This perception was found significantly no different across respondents' provinces and academic qualifications, as shown in Tables 1 and 2.

TABLE I

KRUSKAL- WALLIS TEST RESULT FOR THE IMPORTANCE LEVEL OF TECHNICAL COMPETENCY BASED ON RESPONDENTS' LOCATIONS

\begin{tabular}{|c|c|c|}
\hline Provinces & Mean Rank (N=88) & \multirow{2}{*}{ Asymp. Sig. } \\
\hline East Java & 44.44 & \multirow{2}{*}{.46} \\
\cline { 1 - 2 } South East Sulawesi & 40.79 & \\
\hline Gorontalo & 52.72 & \\
\hline
\end{tabular}

A Kruskal-Wallis test was employed to compare the differences between three or more independent groups. If there were two independent groups, a Mann-Whitney test was employed. Kruskal-Wallis and Mann-Whitney tests were employed in this study since the data was not normally distributed.

The result (Table 1) shows the mean rank score of the importance level of PPK technical competency from respondents resides in East Java, South East Sulawesi and Gorontalo Province (44.44; 40.79; and 52.74 respectively). The asymp. Sig. was .46, which means no significant differences in the respondents' responses on the importance level of technical competency (>.05) based on their workplace locations. It means that most of the respondents acknowledged the importance of having technical competency regardless of workplace location. This importance of technical competency is consistent with Kamal, Hassan, Ismail and Affandi [14], who highlight the need for Client Project Manager in Malaysia to have a certain degree of technical competency.

The findings show that respondents from Gorontalo province valued the technical area is more importnat than respondents in East Java and Southeast Sulawesi. This result might be due to conditions in the Gorontalo province, which may have led respondents to value these competencies more than the other provinces. This finding aligns with the finding that Gorontalo's respondents valued the competencies more and placed more weight on the preferred level of competency. This result might be due to the characteristics of respondents from Gorontalo provinces that none of them 
had more than ten years of experiences in managing construction projects; this might have led those respondents to value technical competency higher than respondents in the other two provinces. However, the differences in the mean rank of the importance level of CPM competency was not significant. It means that most of the respondents agreed on the importance of technical competency regardless of their workplace's locations.

It was also found that there was no statistically significant difference between groups of respondents from engineering and non-engineering academic discipline background, as presented in Table 2 .

TABLE II

MANN-WhitNey TEST RESUlT FOR THE IMPORTANCE LEVEL OF TECHNICAL COMPETENCY BASED ON RESPONDENTS' ACADEMIC DISCIPLINE

\begin{tabular}{|c|c|c|}
\hline Provinces & Mean Rank (N=88) & Asymp. Sig. \\
\hline Engineering & 45.22 & \multirow{2}{*}{.58} \\
\hline Non-engineering & 41.87 & \\
\hline
\end{tabular}

The result (Table 2) shows the mean rank of the importance level of technical competency based on the respondents' academic disciplines (45.22 for engineering and 41.87 for non-engineering). The asymp. Sig value was .58, which means no significant difference in the respondent's responses regarding the importance level of technical competency (>.05). Both respondents from engineering and non-engineering academic discipline perceived the importance of technical competency in managing construction projects. This finding is highly relevant, given the construction industry's nature requiring specialized expertise [25].

The findings obtained from the questionnaire are also consistent with the results of the interview. According to the interviewees, a PPK should have a certain degree of understanding of the technical area because they are responsible for the construction.

"If a PPK does not understand his job technically, a PPK cannot maximally perform his job. So, the understanding of technical-area must be possessed by PPK" (R6 from nonengineering background).

"A PPK must understand his works. As PPK, we have to responsible for the implementation" (R7 from nonengineering background).

The technical area is also perceived as an essential competency by respondents considering it is related to decision-making, and they must responsible for the expenditures.

"We cannot make decisions if we do not have the technical ability. For instance, we build a road, we cannot decide if we do not understand (road) technical area, so this is very important to make decisions. The leader who does not have a technical competency, I think they cannot perform optimally..." (R3 from an engineering background)

". we must have technical competency, (i.e.) how to make a foundation of the structure not to collapse, how to install a bored pile without making the building collapse. We have consultants, but we should also have understanding. Please do not give all to the consultants, whereas the decisionmaker is on our hand, not in the consultants. This is because we are the government; we responsible for the physical and budget. The government is the owner. Have a technical competency is a must, do not just build the road, but then the road is defect/failure (R3 from an engineering background).

Moreover, technical competency is important to be possessed by a PPK to assist them in delegating and supervision process.

"If PPKs do not have a technical competency, automatically they do not know what they must do, then (do not know) what they must delegate, isn't it?...... If we as a PPK do not know the technical area and there is a consultant/ contractor make mistakes or negligence, as the results, we will ignore it. If we have the technical competency and understand the areas that we must do, we can give advice and directions if the mistakes occurred." (R4 from an engineering background)

Even though interviewees agreed on the importance of technical competency for PPK in managing public construction projects, they do not need to know every detail of the technical area.

"When I was given an engineering drawing, and I was asked (by a consultant) to sign, I confused. However, since I am a PPK, I must learn more, but I cannot do the details of the calculation. ( $R 7$ from non-engineering background).

2) Perceived and Preferred level of technical competency. Based on the respondents' self-assessments, the perceived level of technical competency was found in the "average" level (mean score=3.71). Meanwhile, they want to have a 'good" level of competency in the next five years (mean score $=4.43)$. This score makes the gaps between the perceived and preferred level of competency was -.72. These indicate that respondents were aware that their current competency level is in the "average" level, and it needs to be developed to manage public construction successfully.

According to the Kruskal-Wallis test result (Table 3), the mean rank scores of the perceived level of technical competency were 44.28 for respondents in East Java, 44.55 for respondents in South East Sulawesi, and 45.83 for respondents in Gorontalo province. The significance test shows no significant differences in the respondents' responses to the respondents' perceived level of competencybased on the respondents' geographical location (>.05).

Meanwhile, the mean rank scores of the current technical competencies based on the respondents' academic discipline were 46.04 for respondents who hold an engineering degree and 38.92 for respondents from the non-engineering academic discipline. There were statistically no significant differences in the current technical competency level perceived by respondents from engineering and nonengineering backgrounds ( $p>.05)$.

The mean rank score of the preferred level of technical competency based on the respondents' locations were 40.68 , 50.24, and 57.83 for respondents from East Java, South East Sulawesi, and Gorontalo provinces, respectively. The differences were not significantly different, given the Asymp. Sig. value was .055 ( $p>.05)$.

Meanwhile, the mean rank scores for the preferred technical competency level were 43.54 for engineer and 47.97 for non-engineering discipline background. The differences of the preferred level of technical competency between these two groups were also not significant, given the $p$-value was .459 ( $p>.05)$. 
Table 3 presents the summary of the Kruskal-Wallis and Mann-Whitney test on the perceived and the preferred level of competency.

TABLE III

SignificANCE TESt Result For the PERCEIVED AND Preferred LEVEL OF TECHNICAL COMPETENCY

\begin{tabular}{|c|c|c|}
\hline & $\begin{array}{l}\text { Mean Rank } \\
(\mathrm{N}=88)\end{array}$ & Asymp. Sig. \\
\hline $\begin{array}{l}\text { A. Perceived level of } \\
\text { technical competency } \\
\text { Provinces }^{\text {a) }} \\
\square \text { East Java } \\
\square \text { South East Sulawesi } \\
\square \text { Gorontalo } \\
\text { Academic Discipline }{ }^{\text {b) }} \\
\square \text { Engineering } \\
\square \text { Non-engineering }\end{array}$ & $\begin{array}{l}44.28 \\
44.55 \\
45.83 \\
46.04 \\
38.92\end{array}$ & .247 \\
\hline $\begin{array}{l}\text { B. Preferred level of } \\
\text { technical competency } \\
\text { Provinces a) } \\
\square \text { East Java } \\
\square \text { South East Sulawesi } \\
\square \text { Gorontalo } \\
\text { Academic Discipline }{ }^{\text {b) }} \\
\square \text { Engineering } \\
\square \text { Non-engineering }\end{array}$ & $\begin{array}{l}40.68 \\
50.24 \\
57.83 \\
43.54 \\
47.97\end{array}$ & .055 \\
\hline
\end{tabular}

${ }^{a}$ Kruskal-Wallis test

b-Mann-Whitney test

\section{B. Discussion and Recommendation}

The findings show that stakeholder perceives technical competency as a vital competency required by PPK in managing public construction projects. There are three reasons behind this importance: (1) PPK should have a certain degree of understanding of technical area because as a project manager from the in-house client-side, a PPK must be responsible for the construction outputs and construction expenditures; (2) Having technical competency will assists PPK to make decisions related to construction delivery which in turn affecting government budget; (3) Having technical competency will assist PPK in delegating and monitoring contractors' and consultants' works. These findings accord with the previous studies that technical understanding is essential for client project managers in construction projects [14], [26]. Chen and Partington [26] highlighted the importance of project managers in understanding the overall construction process and technical requirements of the construction projects to be able to plan, monitor, give advice, and approve their subcontractors' works. Furthermore, a lack of technical knowledge on client project managers can hinder their understanding and efficiency in making decisions about the problem resolution process [6].

Finding also shows that even though PPK requires technical competency in managing construction, it does not mean that a PPK must understand all the details. A project manager is expected to understand, at least, the big picture of the construction process and the main principles of the construction workings [26], which assist him/her in making appropriate decisions related to project requirements, i.e., cost, schedule, and quality.

It was found from the questionnaire analysis that the mean of the perceived level of technical competency was at the "average" level, and they aware and want to have a better technical competency in the next five years. Another significant finding was the discrepancy of PPK technicalarea competency, suggesting PPK and policymakers to develop this technical competency.

To develop this technical competency, all the interviewees proposed the need for the availability of training that more detail in technical-areas and involve a problem-solving process. What is surprising is that all the respondents revealed that the most current training provided by the central or local government/ agencies had not met their needs yet. The issues of currently provided training raised by interviewees were too general, lack of technical details, not practical, incompetent speakers, lack of problemsolving training, and even the training purposes were unclear.

The findings suggest the need for a comprehensive strategy through the establishment of training and development strategies that support their technical understanding in construction projects. Training is commonly used for a short-term purpose, while development is used for long-term achievement [27]. Training and development are critical because they improve both the technical and generic skills of workers in the construction industry [28].

Some competency development methods obtained from the literature are proposed here as the recommendation to develop PPK's technical competency:

First, identification of training needs should be established. Once training needs in the technical area have been identified, training programs can be organized, such as case studies, role-playing, simulation [29], or on-the-job training.

Second, blended learning could be used as an alternative to developing PPK's technical competency. The availability of blended learning will reduce expenses, provide required course-materials, and provide a typical training environment with mentoring opportunities [30]. Blended learning can be conducted by combining e-learning, self-study, attending class, and on the job training. The proportion of on the job training should be more significant than attending class. The proportion of 70:20:10 that is widely used for learning models and development can be adopted [31]. He explains seventy percent refers to learning through on the job training, 20 percent learning from others (e.g., mentoring), and 10 percent from courses. The availability of the job training can increase PPK's experience in managing public construction as Edum-Fotwe and McCaffer [32]'s statements that the changing construction industry and the demand to maintain their professional competency require project managers to develop their competency through training and experiences consistently. According to Edum-Fotwe and McCaffer [32], competency development can be conducted via formal inhouse training or external courses in the areas that were perceived as lacking.

Third, knowledge sharing mechanisms in the technical area could be used to develop PPK's competency. Project knowledge sharing can be conducted through face to face informal, face to face formal, lessons learned databases, post-project reports, project management office, intellect web tools, or enterprise repositories, e.g., intranet or shareddrive [33]. This method could be supported by providing a 
reward to PPKs willing to share their project experiences since acknowledgment or compensation can positively influence knowledge sharing [34].

\section{CONCLUSION}

This paper has discussed the importance of technical competency perceived by stakeholders. The findings show that having technical competency is essential for PPK to manage public construction successfully. A PPK does not need to have an understanding in every single detail of construction project, but they are expected to understand a big picture of construction methods that enable them to act as a knowledgeable contributor in construction delivery.

This importance of technical competency is acknowledged by respondents regardless of their geographical locations and academic discipline backgrounds; suggesting PPK and policymakers to pay attention to this technical competency. The gap analysis result strengthens the need to conduct training and competency development intervention to enhance PPK technical competency. Blended learning can be conducted as a method to develop CPM technical competency. It combines e-learning, self-study, attending class, and on the job training. The availability of knowledge sharing mechanism was also proposed as a recommendation to develop PPK competency.

This paper has contributed to project management competency knowledge on the need for technical competency for in-house client project managers in public construction projects. The findings will assist PPK to focus and allocate effort on important competency areas, in this regard is technical competency. Another contribution is that the findings might become an empirical basis for other research in other developing countries with similar conditions to Indonesia. It also assists Indonesian policymakers to develop a policy to enhance PPK understanding in the technical area.

This study was limited to the Indonesian context; therefore, further research is required to generalize other countries' findings. A more in-depth investigation of the influence of PPK's technical competency towards project performance is suggested. Furthermore, since this study is based on the PPK's point of view, further study regarding the importance level of PPK technical competency-based on other players in public construction projects can enrich understanding of this topic area. This study is a part of a Ph.D. thesis. The proposed comprehensive strategies to develop PPK competencies are presented in another publication.

\section{ACKNOWLEDGEMENT}

The research was funded by QUTPRA Scholarship.

\section{REFERENCES}

[1] F. Hermawan, H. L. Wahyono, M. A. Wibowo, J. U. Dwihatmoko, and Soetanto, "Toward sustainable practices in building project at Indonesian local government: a case study of construction failure and building failure (defects) Central Java - Indonesia," 6th Civil Engineering Conference in Asia Region (CECAR6), Jakarta, Indonesia, 20-22 August 2013, 10pp.

[2] A. Irmawanto, and C Utomo, "Analisa Faktor Penyebab Kegagalan Proyek Konstruksi di Indonesia Studi Kasus PT. Wijaya Karya (Persero), Tbk. (Factor Analysis of cause-of-construction project failure in Indonesia, Case Study of PT.Wijaya Karya Persero,Tbk.)", National Conference Technology Management XIV, 2011.

[3] C. Z. Oktaviani, "Hubungan Antara Kualitas Pengadaan Pekerjaan Konstruksi Pemerintah Dengan Kualitas Infrastruktur Indonesia (The Relationship between the Quality of Procurement of Public Construction and the Quality of Indonesia's Infrastructure," Seminar Nasional Teknik Sipil V Tahun 2015 -UMS (National Conference, Civil Engineering) V, pp. 286-291, 2015.

[4] J Pos, "Kompetensi Pengawas dan PPK Kurang; Penyebab Proyek Infrastruktur Merugikan Keuangan daerah (Lack of Supervisor and PPKs' competencies; causing Finance Problems in Local Government)," Jawa Pos Newspaper, Indonesia, May 2017.

[5] P Sukabumi, "Pengadaan Barang/Jasa Krisis Pimpro (Crisis of Project Manager in Goods/Services Project)," 2019.

[6] T. M. Ng. S. T. Rose, M. Mak, and S. E. Chen, "Problematic issues associated with project partnering - the contractor perspective," Int. J. Proj. Manag., vol. 20, 6 pp. 437-449, 2002.

[7] D.C. McClelland, "Testing for competence rather than for 'intelligence.'," American Psychologist, vol. 28, 1-14, 1973.

[8] Project Management Institute, Government Extension to the PMBOK® Guide (3rd Edition). Project Management Institute, Inc. (PMI), 2006.

[9] J. Hutcheson, "Educating project managers for the construction industry in Australia," Int. J. Proj. Manag., vol. 2, 4 pp. 220-224, 1984.

[10] A. Vennström, and P. Erik Eriksson, "Client perceived barriers to change of the construction process," Constr. Innov., vol. 10, 2 pp. 126-137, 2010.

[11] L. Jawahar-Nesan, A.D.F. Price, "Formulation of Best Practices for Owner's Representatives,” J Manage Eng, vol.13 pp. 44-51, 1997.

[12] S.K.D. Hutchison, "Client best practice guide," Thomas Telford Ltd, London, UK, 2009.

[13] P. Thompson, "The client role in project management," Int. J. Proj. Manag., vol. 9, 2 pp. 90-92, 1991.

[14] M. F. M. Kamal, F. Hassan, Z. Ismail, and H. M. Affandi, "Technical competency of client project manager in managing public projects in Malaysia," 2012 IEEE Colloquium on Humanities, Science and Engineering (CHUSER), pp. 48-51, 2012.

[15] K. P. Negara, F. Lamari, C. Susilawati, and B. Trigunarsyah, "Identifying client project manager competency in Indonesian construction project," MATEC Web of Conferences, International Conference on Advances in Civil and Environmental Engineering (ICAnCEE 2018), vol. 276, 2019.

[16] Z. Isik, D. Arditi, I. Dikmen, and M. T. Birgonul, "Impact of Resources and Strategies on Construction Company Performance," $J$. Manag. Eng., vol. 26, 1 pp. 9-18, 2010.

[17] S. El-Sabaa, "The skills and career path of an effective project manager," Int. J. Proj. Manag., 2001.

[18] K. T. Odusami, "Perceptions of Construction Professionals Concerning Important Skills of Effective Project Leaders," J. Manag. Eng., 2002.

[19] D. Walker, "The contribution of the client representative to the creation and maintenance of good project inter-team relationships," Eng. Constr. Archit. Manag., vol. 5, 1 pp. 51-57, Sep. 1998.

[20] G. Gable, "Integrating case study and survey research methods: an example in information systems," Eur J Inform Syst, vol.3 pp.112126, 1994.

[21] J.W. Creswell, "Qualitative inquiry \& research design: choosing among five approaches," Fourth edition. ed., SAGE, Thousand Oaks, CA, 2018.

[22] M.Q. Patton, "Qualitative evaluation and research methods", 2nd ed., Sage Publications,Inc, 1990.

[23] J.W. Creswell, A.C. Klassen, V.L. Plano Clark, K.C. Smith, "Best practices for mixed methods research in the health sciences," Bethesda (Maryland): National Institutes of Health, pp. 2094-2103, 2011.

[24] Badan Pusat Statistik Indonesia, "Nilai Konstruksi yang Diselesaikan Perusahaan Konstruksi Menurut Provinsi dan Bidang Pekerjaan Utama (Juta Rupiah) 2010-2015 (The amount of Completed Construction based on Provinces and Main Work Sector-in Million Rupiah)", Indonesian Government Report, 2016.

[25] P. M. Institute, "Construction Extension to the PMBOK® Guide," Project Management Institute, Inc. (PMI), 2016.

[26] P. Chen, and D. Partington, "Three conceptual levels of construction project management work," Int. J. Proj. Manag., vol. 24, pp. 412-421, 2006. 
[27] A.M. Saks, "Managing performance through training and development," 4th ed. ed., Thomson Nelson, Toronto, 2007.

[28] N. Detsimas, V. Coffey, Z. Sadiqi, M. Li, "Workplace training and generic and technical skill development in the Australian construction industry," J. of Manag. Dev., vol. 35, pp. 486-504, 2016.

[29] A. A. Tabassi, and A. H. A. Bakar, "Training, motivation, and performance: The case of human resource management in construction projects in Mashhad, Iran," Int. J. Proj. Manag., vol. 27, 5 pp. 471-480, 2019.

[30] T.A. Carbone, "Developing Project and Program Managers: A Blended Learning Approach", in: The 17th Annual SEMI/IEEE ASMC 2006 Conference, pp. 353-357, 2006.
[31] T. Bergin, "Learning and Development in the Public Sector", 2013.

[32] F.T. Edum-Fotwe, R. McCaffer, "Developing project management competency: perspectives from the construction industry", Int. J. Proj. Manag., vol.18, pp. 111-124, 2000.

[33] A. Wiewiora, "The role of organisational culture, trust and mechanisms in inter-project knowledge sharing", in: A. Wiewiora, D. Queensland University of Technology. School of Urban, A Wiewiora (Eds.), 2011.

[34] D. Burgess, What Motivates Employees to Transfer Knowledge Outside Their Work Unit?, Journal of Business Communication, vol. 42 pp. 324-348, 2005. 